ISSN 1029-8940 (Print)

ISSN 2524-230X (Online)

\title{
ВУЧОНЫЯ БЕЛАРУСІ
}

SCIENTISTS OF BELARUS

\section{АНАТОЛИЙ ИВАНОВИЧ ЗИНЧЕНКО \\ (К 75-летию со дня рождения)}

28 ноября 2021 г. исполнилось 75 лет со дня рождения известного ученого в области биотехнологии соединений нуклеиновой природы, члена-корреспондента НАН Беларуси (2000), доктора биологических наук (1993), профессора (2006), заведующего лабораторией молекулярной биотехнологии Института микробиологии НАН Беларуси Анатолия Ивановича Зинченко.

Родился Анатолий Иванович в шахтерском поселке Щеголовка Сталинской (ныне Донецкой) области (Украина). Трудовой путь начал слесарем на Минском тракторном заводе (1963-1965 гг.). В 1970 г. окончил с отличием биолого-почвенный факультет Московского государственного университета им. М. В. Ломоносова, а в 1973 г. аспирантуру биологического факультета МГУ, успешно защитив кандидатскую диссертацию. В 1974-1982 гг. работал старшим инженером, младшим, старшим научным сотрудником Института биоорганической химии АН БССР. С 1982 г. научная жизнь

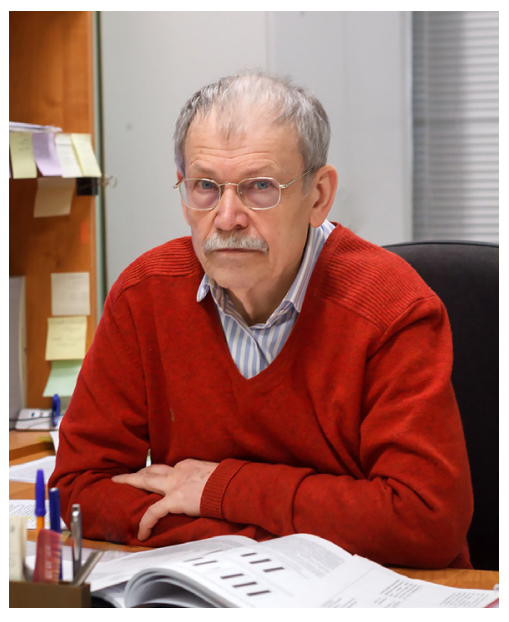
А. И. Зинченко неразрывно связана с Институтом микробиологии НАН Беларуси, где он прошел путь от старшего научного сотрудника (1982) до заведующего лабораторией Института (с 1989 г. по настоящее время).

Увлеченность наукой у Анатолия Ивановича зародилась в годы учебы в МГУ под влиянием общения с профессорами Томасом Иосифовичем Тихоненко, Вадимом Израилевичем Аголом и Иосифом Григорьевичем Атабековым, которые организовали на биолого-почвенном факультете МГУ кафедру вирусологии. Со студенческой скамьи Анатолия Ивановича больше всего привлекали медицинские приложения молекулярной биологии.

Основными направлениями его научно-практической деятельности являются конструирование высокоактивных штаммов бактерий - сверхпродуцентов ферментов нуклеинового обмена, разработка биотехнологии получения природных и модифицированных нуклеотидов и нуклеозидов, востребованных в производстве фармакологически важных соединений и реагентов для ПЦР. А. И. Зинченко инициированы исследования по генной инженерии микроорганизмов. Им же опубликована первая в Республике Беларусь экспериментальная работа в этой области. В последнее десятилетие под его руководством сконструировано более 30 рекомбинантных штаммов микроорганизмов.

А. И. Зинченко была создана научная школа «Биотехнологии соединений нуклеиновой природы». Необходимость ее создания была обусловлена растущей потребностью здравоохранения республики в отечественных противовирусных и противоопухолевых лекарственных препаратах на основе нуклеиновых кислот и их структурных компонентов.

Разработки Анатолия Ивановича дважды входили в топ-10 результатов ученых НАН Беларуси в области фундаментальных и прикладных исследований.

Фундаментальные исследования, проводимые А. И. Зинченко, легли в основу разработанных совместно с Институтом биоорганической химии НАН Беларуси (ИБОХ НАН Беларуси) оригинальных химико-ферментативных технологий получения лекарственных субстанций высокоэффективных отечественных противоопухолевых препаратов «Лейкладин» и «Флударабел». В 2004 г. за данный цикл работ А. И. Зинченко совместно с коллегами удостоен Государственной премии Республики Беларусь в области науки и техники. Ежегодно по технологиям, разработанным под руководством А. И. Зинченко, выпускаются и поставляются в НПЦ «ХимФармСинтез» ИБОХ НАН Беларуси рекомбинантные нуклеозидфосфорилазы, которые обеспечивают промышленное производство отече- 
ственных препаратов для терапии лейкозов и рассеянного склероза. А. И. Зинченко совместно с учеными из ИБОХ НАН Беларуси был установлен молекулярный механизм активации ключевого биокатализатора в синтезе компонентов нуклеиновых кислот (пуриннуклеозидфосфорилазы), позволивший определить исходные нуклеозиды для создания лекарственных препаратов с противоопухолевой и противовирусной активностью и синтезировать фармакологически перспективные фторпроизводные дезокси- и дидезоксинуклеозидов (топ-10 за 2015 г.).

А. И. Зинченко предложена идея устранения защиты рака от хозяйского иммунитета с помощью фермента аденозиндезаминазы, слитой с белком аннексином-А5. Впервые в Беларуси с использованием генно-инженерной техники созданы рекомбинантные штаммы бактерий - продуценты аденозиндеградирующих ферментов, слитых с человеческим белком, который при введении в организм человека и животных связывается только с раковыми клетками. Полученные результаты исследования открывают возможность создания оригинальных таргетных биопрепаратов, способных снять аденозиновую блокаду опухоли и «разбудить» собственный противораковый иммунитет онкологических больных (топ-10 за 2020 г.).

Под руководством А. И. Зинченко реконструирована бактериальная бесклеточная система трансляции для получения белковых продуктов, синтез которых традиционным способом, предусматривающим использование целых бактериальных клеток, затруднен или невозможен. С ее помощью синтезирован ряд хозяйственно ценных белков, в том числе субъединица бактериального токсина для создания вакцины против энтеритов крупного рогатого скота и растительный белок интенсивносладкого вкуса - браззеин. Этот белок характеризуется безвредностью и практически не имеет калорийности, что открывает перспективу создания сахарозаменителя нового поколения для нужд медицины и пищевой промышленности.

Научные труды А. И. Зинченко широко известны в республике и за рубежом. Он автор более 400 научных публикаций, 20 авторских свидетельств СССР на изобретения и 18 патентов Республики Беларусь. Индекс Хирша его публикаций составляет 11 (по базе данных Scopus).

А. И. Зинченко уделяет много внимания подготовке научных кадров высшей квалификации, руководит созданным в 2008 г. на базе Института микробиологии НАН Беларуси филиалом кафедры экологической химии и биохимии УО «Международный государственный экологический институт им. А. Д. Сахарова БГУ». Им разработаны программы спецкурсов «Биотехнология» и «Молекулярная биология вирусов и противовирусная терапия», которые он более 20 лет преподает студентам этого вуза. В 2005 г. А. И. Зинченко издан одобренный Министерством образования Республики Беларусь учебник по молекулярной биологии вирусов и антивирусной терапии для студентов высших учебных заведений, не потерявший своей актуальности до сих пор.

Под руководством А. И. Зинченко защищено 9 кандидатских и 3 магистерских диссертации, 40 дипломных работ.

С 2012 по 2018 г. А. И. Зинченко входил в состав экспертного совета ВАК Республики Беларусь по специальности «микробиология». С 1995 по 2012 г. и с 2018 г. по настоящее время он является членом совета по защите диссертаций Д 01.34.01 при Институте микробиологии НАН Беларуси.

Результаты профессиональной деятельности А. И. Зинченко отмечены юбилейной медалью «В честь 80-летия НАН Беларуси» (2009 г.), памятными знаками «В честь основания НАН Беларуси» (2014 г.) и «В честь 90-летия НАН Беларуси» (2018 г.), почетными грамотами различных министерств и ведомств. В 2016 г. ему объявлена благодарность Белорусского государственного университета за многолетнюю плодотворную трудовую деятельность в связи с 95-летием со дня основания БГУ.

Говоря о А. И. Зинченко как об ученом и человеке, следует отметить его прекрасные организаторские способности, большую работоспособность, высокую эрудицию, оригинальность мышления, настойчивость в достижении поставленных целей, порядочность, отзывчивость и доброжелательность. Анатолий Иванович пользуется большим уважением среди коллег.

Отделение биологических наук НАН Беларуси и коллектив Института микробиологии НАН Беларуси сердечно поздравляют Анатолия Ивановича с юбилеем и желают ему крепкого здоровья и новых научных достижений на благо белорусской науки.

Отделение биологических наук НАН Беларуси, коллектив Института микробиологии НАН Беларуси 